URI J. HUPPERT ${ }^{1}$

\title{
Jerozolima w potrzasku między Watykanem, Moskwą, ewangelikami republikańskimi, mesjanizmem judaistycznym i islamem
}

\section{Streszczenie}

Jerozolima, a szczególnie Góra Świątynna (Moria), została uświęcona przez trzy największe monoteistyczne religie. Przez judaizm - przez poświęcenie Izaaka (Stary Testament), ustanowienie Jerozolimy przez króla Dawida stolicą starożytnego państwa Izraelitów i dwie zburzone świątynie. Przez chrześcijaństwo - Chrystus modlił się w Drugiej Świątyni, został w Jerozolimie ukrzyżowany i pochowany. Na tejże Górze Świątynnej, na gruzach Drugiej Świątyni, posadowiono meczet muzułmański Al Aksa.

Współczesny konflikt wyznaczony został przez: powstanie Państwa Izraela (1948) i opanowanie wschodniej Jerozolimy (1967), wpływy Moskwy poprzez prawosławie i kościoły orientalne, wpływ polityczny mesjanizmu żydowskiego przy masowym wsparciu fundamentalizmu ewangelickiego poprzez partię republikańską w Stanach Zjednoczonych, konflikt islamu z Zachodem i Izraelem, skoncentrowany wokół Jerozolimy jako punkt zapalny „współczesnych Mesjaszów”.

Słowa kluczowe: fundamentalizm, Jerozolima, konflikt, Bliski Wschód

1 Dr Uri Huppert - adwokat, Jerozolima; emerytowany wykładowca Cleveland State University, Kent State University i Akademii Leona Koźmińskiego. 


\title{
URI J. HUPPERT
}

\section{Jerusalem Trapped between Vatican, Moscow, Republican Evangelism, Judaic Messianism, and Islam}

\begin{abstract}
Jerusalem, especially the Temple Mount (Moriah), has been sanctified by the three biggest monotheistic religions. By Judaism - the binding of Isaac (Old Testament), King David pronouncing Jerusalem the capital of the ancient country of Israelites, and two demolished temples. By Christianity -Christ prayed in the Second Temple, becoming later crucified and buried in Jerusalem. The ruins of the Second Temple became the site where the Muslim Al-Aqsa Mosque was built.

The contemporary conflict is marked by: the emergence of the State of Israel (1948) and the capturing of Jerusalem (1967), Russian influences exerted by the Orthodox Church and Oriental churches, the political impact of Jewish messianism combined with a mass support for evangelical fundamentalism as offered by the Republican Party in the US, the conflict between the West and Israel, focusing on Jerusalem as the tinderbox for "contemporary messiahs"
\end{abstract}

Keywords: fundamentalism, Jerusalem, conflict, Near East 


\section{Wprowadzenie}

W roku 1983, 36 lat temu, amerykańskie pismo politologiczne „Executive Intelligence Review" rzuciło złowieszczą prognozę: „Temple Mount fundamentalists launching new Mideast holy wars".

Prowokacyjne hasło, rzucone przez amerykański przegląd politologiczny, oparło się, bez wątpienia, na dwóch twardych faktach: w roku 1967 Izrael opanował cały obszar nad rzeką Jordan i inkorporował całą Jerozolimę, włącznie z Górą Świątynną. Już w latach 70. poprzedniego stulecia formowało się w Stanach Zjednoczonych prawicowe ugrupowanie, znane później jako "Moral Majority”, by w imię "autentycznych amerykańskich walorów moralnych" zahamować falę organizacji liberalnych działających pod hasłem równości i praw jednostki.

\section{Jerozolima między denominacjami}

Niniejszy artykuł ma na celu przedstawienie problematyki i konfliktu z Kościołem rzymskim (katolickim) oraz kościołami orientalnymi, reprezentowanymi przez prawosławie moskiewskie. W ten konflikt włączył się świat muzułmański, a ostatnio judaizm reprezentowany przez siłę militarną Izraela, jakże błyskotliwie ukazaną w doskonale strategicznie rozpracowanej Wojnie Sześciodniowej.

Każdy turysta z łatwością potwierdzi wiekową oraz fizyczną obecność kościołów wschodnich w Jerozolimie, a szczególnie tych rosyjskich, finansowo wspieranych przez władze moskiewskie - nie tylko carskie, a nawet działające pod egidą Związku Radzieckiego, a dziś Rosji Putina (znane ówcześnie jako „czerwona cerkiew"). W sercu Jerozolimy wielka cerkiew króluje nad tzw. Dzielnicą rosyjską (Russian Compound) i potwierdza więź Moskwy z Jerozolimą.

Współcześnie zrodzona w Ameryce Północnej nowa denominacja chrześcijańska, wywiera polityczny, i z dnia na dzień bardziej widoczny, wpływ na politykę Izraela, Palestyny i Jerozolimy. Jest nią konserwatywny, fundamentalistyczny ruch ewangelicki o zacięciu antyliberalnym. 


\section{Jerozolima - Bliski Wschód}

Jak już wspomniałem, ramy tego artykułu ograniczają się do problematyki jerozolimskiej. Trudno jednak problematykę tę odizolować od faktu lokalizacji Jerozolimy na kontynencie Bliskiego Wschodu.

Konceptualnie nie można też odizolować głównego nurtu syjonizmu od świeckiej wizji państwa izraelskiego, co niniejszym odnotowuję.

Zaznaczam, w ramach tego referatu, że pierwotna koncepcja z premedytacją odseparowała element świecko-narodowy od tradycyjnego spojenia religii w ortodoksyjny judaizm. Syjonizm polityczny nie wiązał religii mojżeszowej z przynależnością narodową (tematyka ta znana jest w wyrokach Sądu Najwyższego w Jerozolimie i w literaturze politologicznej-odniosłem się do niej w kilku polskich publikacjach, włącznie z książkowym opracowaniem² ${ }^{2}$.

\section{Jerozolima w kontekście narodowym}

Starając się zadbać o ograniczone ramy tego artykułu, czuję się jednak w obowiązku wspomnieć na marginesie nową pracę jerozolimskiego historyka, dr. Dimitra Shumskiego pt. Beyond the National State ${ }^{3}$.

Dr Shumsky intryguje paroma zasadniczymi pytaniami: czy celem syjonizmu było powstanie państwa narodowego? Czy suwerenność narodu żydowskiego w biblijnej kolebce nie przewidywała koncepcji wielonarodowej? Czy autonomia narodowa Żydów nie była przemyślana jako odrębny okręg ówczesnego Imperium Osmańskiego, a może ówczesnego CK Austro-Węgierskiego albo jeszcze polskiej Rzeczpospolitej Obojga Narodów?

Pytania dr Shumskiego są szczególnie aktualne, tak w odniesieniu do amerykańskiego wizji ewangelickiej, siłowo realizowanej przez Stany Zjednoczone odnośnie Jerozolimy, jak w odniesieniu do „ustawy o narodzie”, przeforsowanej ostatnio przez premiera Netanjahu. Ta ustawa zaostrza konflikt z mniejszościami narodowymi, a ekspozycja identyfikacji religijnej odbija się na stosunkach z islamem. Muzułmanie żądają przywrócenia kalifatu, który naturalnie ma objąć Jerozolimę jako muzułmańskie święte miasto "Al Quds".

W niniejszym artykule postaram się przedstawić punkt widzenia, iż ewangeliści -w imię rozumianej przez siebie racji stanu konserwatywnej Ameryki - wysługują się, bez żenady, żydowskimi mesjanistami, by w drodze do ustanowienia w Jero-

2 U. Huppert, Izrael w cieniu fundamentalizmów, Wydawnictwo Adam Marszałek, Torun 2016.

3 D. Shumski, Beyond the National State, Yale University Press 2019. 
zolimie, na Wzgórzu Świątynnym „ponownego przyjścia Chrystusa”, doprowadzić do pożogi ze światem islamskim i z Moskwą.

\section{Ewangeliści a upolityczniona teologia}

W latach 70. ubiegłego wieku miniaturowe kościoły antykatolickie stworzyły unię pod nazwą "Moral Majority”.

Ta społeczność, licząca ówcześnie 45 milionów członków, w tej chwili-w XXI wieku - oceniana jest na 65 milionów w Stanach Zjednoczonych i na miliony w Brazylii i Skandynawii. Dziś ewangelicy, jako konserwatyści, dominują w partii republikańskiej i nadają ton polityce Republikanów na Bliskim Wschodzie i w Izraelu dzięki mesjanistyczno-ortodoksyjnej prawicy, której podporządkowała się prawie połowa izraelskiego elektoratu.

W Jerozolimie doszło do ewidentnej konfrontacji trzech religii:

$\square$ judaizmu religijnego, skłóconego teologicznie i politycznie między ortodoksją, konserwatyzmem i liberalizmem reformowym, stanowiącym decydującą większość wśród Żydów amerykańskich.

$\square$ chrześcijaństwa zachodniego i wschodniego, z mocnym czynnikiem prawosławnym pozostającym pod wpływem politycznym Moskwy.

$\square$ islamu sunnickiego pod egidą Saudii i Jordanii, szyickiego, kierowanego przez Iran.

Ortodoksyjny judaizm uważa się etnocentrycznie za naród posiadający religię. Tradycyjny kierunek islamu za naród uważa, podobnie do judaizmu, że naród opiera się na wspólnej muzułmańskiej więzi religijnej.

Powiązanie z Jerozolimą komplikuje się w odniesieniu do dwóch znaczących odłamów chrześcijaństwa: prawosławny kościół moskiewski uważa się za spadkobiercę kościoła bizantyńskiego, a zatem za kustosza miejsc świętych Bliskiego Wschodu, szczególnie Jerozolimy.

\section{Unarodowienie Bliskiego Wschodu}

Współcześnie trzy dramatyczne wydarzenia wstrząsnęły Bliskim Wschodem, który przez setki lat znajdował się pod egidą tureckiego, muzułmańskiego (sunnickiego) Imperium Osmańskiego.

Po zakończeniu I wojny światowej, a wcześniej w roku 1916, trzy ówczesne mocarstwa planowały dokonania dramatycznego podziału państwa tureckiego 
i Bliskiego Wschodu. Sygnatariuszami nowego ładu miały być: carska Rosja, Francja i Wielka Brytania. Rewolucja świeckiego bolszewizmu i upadek Rosji carskiej pozostawiły przy stole obrad Wielką Brytanię i Francję. Ambicje Moskwy nie zostały skonsumowane na tym etapie.

Ostatecznie w roku 1916 porozumienie o podziale Bliskiego Wschodu został zrealizowane. Układ ten, noszący nazwiska jego sygnatariuszy, Sykesa-Picota, stał się faktem dokonanym ${ }^{4}$, i tak, na plemiennych gruzach powstawały "narodowe" państwa arabskie: Trans-Jordania, Irak, Syria, Liban i Palestyna (od Morza Śródziemnego po rzekę Jordan na wschodzie). Palestyna, pod egidą Ligi Narodów, podlegała de facto Wielkiej Brytanii jako „mandat”, nie była więc kolonią Zjednoczonego Królestwa.

Ustanowiono, że Jerozolima będzie stolicą mandatu. Tak powrócono do biblijnej tradycji sięgającej izraelickiej stolicy króla Dawia sprzed trzech tysięcy lat i krzyżackiego średniowiecznego „królestwa Jerozolimy”, odbitego muzułmanom na niecałe dwieście lat. Ten porządek, narysowany przez Francję i Wielką Brytanię, przetrwał około stu lat.

\section{Domy narodowe dla upośledzonych}

Druga wojna światowa znacznie osłabiła Francję i Wielką Brytanię. Mimo alianckich zwycięstw, lecz nie mniej przez oświecenie, które wzmocniło prawa jednostki i prawo do narodowego samostanowienia (które wykiełkowało już w XIX wieku), powstała gleba do ruchu wyzwoleńczego niewolników amerykańskich.

W roku 1847 powstała w zachodniej Afryce niepodległa Liberia, a w 1808 roku koronna kolonia Sierra Leona (niepodległa od roku 1961), jako nowa ojczyzna brytyjskich niewolników.

Nawet Józef Stalin włączył się do przywódców, którzy zainicjowali rozwiązanie problemu samostanowienia Żydów „wschodnich” (ostjuden), ofiar pogromów. Stalin uważał, ze naród charakteryzuje się obecnością na określonym terytorium.

Jak stwierdza dr Artur Patek „za rządów carskich losy (Żydów) stały pod znakiem prześladowań, dyskryminacji i pogromów" ${ }^{\prime \prime}$. Masy Żydów wschodnich, mniej wykształcone w porównaniu z wyemancypowanymi Żydami Zachodu, otrzymały jakoby swe narodowe rozwiązanie w "Żydowskim Obwodzie Autonomicznym" w Związku Radzieckim wraz z chińskimi, koreańskimi i słowiańskimi tubylcami.

Zob. M. Górny, Kreślarze ojczyzn, PAN, Warszawa 2018.

5 A. Patek, Birobidżan. Sowiecka ziemia obiecana, wyd. Historia Iagellonica, Kraków 1997. 


\section{Izrael - nowa rzeczywistość}

Równolegle James Balfour, minister spraw zagranicznych Wielkiej Brytanii, rzucił w 1916 roku hasło „Home for Jewish People in Palestine”, mając chyba jednak przed oczyma wyemancypowanych Żydów Zachodu.

I tak 29 listopada 1947 roku Ogólne Zgromadzenie ONZ uznało powstanie na części terenu mandatoryjnej Palestyny państwa dla Żydów. W odpowiedzi ościenne państwa arabskie (Egipt, Transjordania, Irak, Liban, Syria) zaatakowały zalążek nowego państwa. Nowonarodzone Państwo Izraela odepchnęło agresorów, a w maju 1948 roku zostało proklamowane.

W wyniku tej wojny, zwanej „wyzwoleńczą", Jerozolima Zachodnia pozostała po stronie izraelskiej. Jerozolima Wschodnia, wraz ze Starym Miastem i Górą Świątynną - „Morią” - stała się częścią Haszemickiego Królestwa Jordanii. Warto zaznaczyć, że Legion Arabski, pomimo opanowania Starego Miasta Jerozolimy, zachował swą stolicę w Ammanie.

Podział Jerozolimy został zlikwidowany w wyniku Wojny Sześciodniowej, a 30 czerwca 1980 roku izraelski parlament (Kneset), pod rygorem ustawy zasadniczej (Dziennik Ustaw Izraela Nr 980 z 5 sierpnia 1980 r.), inkorporował Jerozolimę (poszerzoną o małe miejscowości, nieleżące wcześniej w granicach „mandatoryjnej” Jerozolimy), ustanawiając ją stolicą Państwa Izrael.

Ustawa Knesetu kolidowała jednak z decyzją podziału Palestyny z dnia 29 listopada 1947 roku. Decyzja nr 181 Ogólnego Zgromadzenia ONZ opiewa, że Jerozolima w municypalnych granicach "mandatu” stanowić będzie „wolne miasto". Watykan do dziś uważa tę decyzję za wiążącą.

\section{Watykan, Izrael za Jana Pawła II}

W tym kontekście godny szczególnej uwagi był oficjalny przyjazd do Jerozolimy papieża Jana Pawła II, który nie tylko odbył pielgrzymkę do Ziemi Świętej, lecz ostentacyjnie dnia 22 marca 2000 roku odwiedził w Jerozolimie instytut "Yad VaShem", spotykając się z byłymi wadowiczanami - przyjaciółmi ze szkolnej ławy, jak również spotykając się oficjalnie z prezydentem Izraela w jego rezydencji w Jerozolimie, a także z premierem Izraela Ehudem Barakiem. Papież złożył również symboliczną kartkę przy Ścianie Płaczu, reminiscencji Drugiej Świątyni, zburzonej przez rzymskiego Tytusa. Był to, bez wątpienia, ewidentny akt polityczny.

26 października 1994 roku król Jordanii Hussein i premier Izraela Icchak Rabin wspólnie uznali, że Jordania rezygnuje ze swych praw do mandatoryjnej Palestyny, a Izrael - na mocy paragrafu 9 Układu Pokojowego - uznaje specjalną pozycję 
muzułmańskich świętych miejsc w Jerozolimie. Powyższy paragraf kończy się następującą deklaracją: „The Parties will act together to promote interfaith relations among the three monotheistic religions, with the aim on working towards religious undestanding, moral commitment, freedom of religious worship, and tolerance and peace".

Dzięki temu traktatowi król Hussein - jako potomek Mahometa - w imię sunnickiego islamu utrzymał pozycję świata muzułmańskiego również ze strony nowego suwerena Jerozolimy, którym de facto stało się Państwo Izralea.

\section{Ewangelicy jako neo-syjoniści}

W roku 1981 premier Izraela Menachem Begin spotkał się z przywódcą "Moral Majority", pastorem Jerry Falwellem. W spotkaniu uczestniczył ówczesny anonimowy młody dyplomata - Binjamin Netanjahu.

W tym miejscu rozpoczął się wielki i jakże znaczący romans między żydowskimi mesjanistami i izraelską prawicą oraz wpływową organizacją ewangelickich chrześcijan, kierujących polityką blisko-wschodnią Partii Republikańskiej na waszyngtońskim Kapitolu i w Białym Domu (poprzez republikańskich prezydentów takich jak Ronald Reagan, obaj Bushowie i Donald Trump).

Na tym etapie naszego dyskursu należy, w wielkim skrócie, przedstawić trzy tysiące lat historii świętego miasta - Jerozolimy.

Trzy tysiące lat dziejów Jerozolimy przedstawia Biblia. Księga Rodzaju opisuje dramat poświęcenia Izaaka na Górze Moria, znanej nam współcześnie jako Góra Świątynna (Księga Rodzaju, rozdział 22, 1-2). Niedoszłe poświęcenie Izaaka wspomina także Nowy Testament (Hebr. 11, 17-19).

Król Dawid, władca i symbol zjednoczonego królestwa izraelickiego, wyznaczył Jerozolimę jako stolicę i władał nią od 1040 r. p. n. e. (przypuszczalnie zmarł w 970 r. p. n. e.). Tradycja głosi, że został pochowany na jerozolimskiej Górze Syjonu. Tam też ponoć Chrystus odbył „ostatnią wieczerzę”. To wzgórze Jerozolimy było również symbolem narodowego ruchu syjonistycznego.

Wyjątkowe, boskie pochodzenie Jerozolimy wiąże się także z Chrystusem, urodzonym w Betlejem. Jak opisuje Nowy Testament, w jerozolimskiej świątyni na Górze Świątynnej - Morii, modlił się Chrystus, a później - w Jerozolimie - został on ukrzyżowany. W tejże Jerozolimie znajduje się - w sercu Starego Miasta, w dzielnicy chrześcijańskiej - grób Chrystusa.

Jednak ten monoteistyczny duet judeo-chrześcijaństwa został w VII wieku dramatycznie naruszony. 


\section{Muzułmanie zdobywają Bliski Wschód}

Ponad tysiąc pięćset lat rywalizacji chrześcijaństwa z judaizmem, pomimo wspólnego pnia, wykazało bezprecedensową siłę przebicia dwóch wersji chrześcijaństwa - tak zachodniej, jak wschodniej.

Chrześcijaństwo do dnia dzisiejszego jest największą monoteistyczną religią świata. Judasz Eskariota został w Nowym Testamencie (ewangelie według św. Mateusza, św. Marka i św. Łukasza) oskarżony jako zdrajca, który wydał Chrystusa rzymskim oprawcom.

Pokolenia chrześcijan oskarżały Żydów za pochodzących od Judasza, a represje stosowane wobec Żydów miały jakoby zdradę Judasza upamiętnić. Żydzi mieli do końca wszystkich pokoleń płacić krwią za domniemaną zdradę.

Judeo-chrześcijański „monopol” na monoteizm został jednak podważony. Nowy prorok monoteizmu, Mahomet (żyjący najprawdopodobniej w latach 570-632 n. e.) wstąpił z wielkim impetem na arenę światowych religii. Nowy wieszcz monoteizmu promował walkę orężem o prymat religijny na świecie.

Podług wiążącej muzułmanów tradycji, z woli Boga (Allaha) Mahomet napisał Wielki Manifest, znany jako Koran. Koran, jako święta księga islamu, wspomina jedynie dwa ośrodki kultu: Mekkę i Medynę.

Jerozolima, jako święte miasto (Al Quds), jest jedynie tworem tradycji, która opisuje, iż prorok Mahomet na swym rumaku zwanym „Burak” wzniósł się ponoć do nieba, odbijając się od Wzgórza Świątynnego. Odcisk kopyta uświęconego rumaka widzą ponoć jego wyznawcy. Tu, na gruzach Drugiej Świątyni, muzułmanie wybudowali meczet Al Aqsa i tak konflikt judeo-chrześcijański przeobraził się w konflikt z liczącym dziś 1,8 miliarda wyznawców islamu.

Watykan jako czynnik polityczny Zachodu zniknął z horyzontu Bliskiego Wschodu (nadal częściowo wspierając odrębny status Jerozolimy), a moskiewskie prawosławie przejęło inicjatywę. Zachód europejski działał w imię swej cywilizacji (Wielka Brytania, Francja), nie promując jednak opcji religijnej.

\section{Ponad 60 sprzecznych propozycji rozwiązania konfliktu jerozolimskiego}

Wspomniany już artykuł amerykańskiego czasopisma z 1983 roku i ostatnio opublikowany artykuł w piśmie „Economist” (marzec 2019) ostrzegają Izrael i Bliski Wschód przed katastrofą.

Rok 1967 wprowadził na arenę polityczną odnowienie gracza: mesjanizmu w kontekście terytorialnym i politycznym. 
Ks. Stanisław Łach pisze: „Mesjanizm należy obok monoteizmu do centralnych idei całej Biblii. W księgach Starego Testamentu występuje w formie raz po raz głoszonej obietnicy, że Jahwe ześle Izraelowi i całej ludzkości Zbawcę, zwanego Mesjaszem, który usunie z ziemi wszelką niesprawiedliwość i wojny i zapoczątkuje na ziemi królestwo Boże pełne wszelkiej szczęśliwości i pokoju. W księgach zaś Nowego Testamentu mesjanizm zjawia się jako wypełnienie obietnicy, gdyż Chrystus z Nazaretu jest tu przedstawiony jako zapowiedziany Mesjasz"6. Ks. Łach kontynuuje, odnosząc się do bardziej współczesnych teorii: „Mesjanizm mieli stworzyć późniejsi prorocy, którzy po ugruntowaniu monoteizmu poczęci snuć różne domysły na przyszłość, ale raczej o charakterze politycznym. Dopiero klęski narodowe Izraelitów, upadek ich państwa, uprowadzenie do niewoli, stało się bezpośrednim źródłem mesjanizmu z jego obrazami restauracji Izraela i jego wiecznym królestwie Syna Człowieczego, które nastąpi po poniżeniach Izraela i dynastii Dawidowej, przedstawionej w obrazie Sługi Boga".

Wojna Sześciodniowa była wyjątkowo udaną eskapadą świeckich władz za rządów premiera Lewi Eszkola, jego ministra obrony gen. Mosze Dayana i szefa sztabu - przyszłego socjalistycznego premiera - Icchaka Rabina.

Dawid Ben Gurion w wywiadzie dla gazety Haaretz zadeklarował, odnosząc się do terytorialnych sukcesów Izraela: „Ja optuję za utworzeniem państwa palestyńskiego poza Jerozolimą i jej okolicami” i dodał: „ostrzegam przed okupowaniem innego narodu i represjami z tym związanymi".

Działający w Jerozolimie Jerusalem Institute wydał szczegółową listę 62 propozycji na rozwiązanie konfliktu religijnego i politycznego (The Jerusalem Institute for Israel Studies, The Hay Elyachar House, 1994 r.). Przytoczę jedynie kilka z nich:

$\checkmark$ wspomniany układ Sykes-Picot proponuje dla Palestyny, włącznie z Jerozolimą, zwierzchnictwo międzynarodowe (ostatecznie Wielka Brytania otrzymała mandat od Ligi Narodów, stając się formalnie powiernikiem, a de facto - władcą Palestyny);

$\square$ karta mandatu (1922 r.) oddała Wielkiej Brytanii odpowiedzialność za Jerozolimę;

$\square$ decyzją nr 181 Zgromadzenie Ogólne ONZ zaopiniowało, by Jerozolima stała się corpus separatum pod egidą międzynarodową;

u w propozycji Izraela z dnia 26 maja 1950 roku (w okresie podziału Jerozolimy pomiędzy Izraelem a Jordanią) ONZ uczyniono odpowiedzialnym za miejsca kultu w Jerozolimie;

6 S. Łach, Geneza mesjanizmu biblijnego, „Ruch Biblijny i Liturgiczny” 1970, nr 4-5, s. 167. 
- propozycja z dnia 2 lipca 1968 roku zastępcy burmistrza Jerozolimy: 1) otwarty cały okręg municypalny pod władzą Izraela; 2) podział Jerozolimy na samodzielne gminy podług charakteru mieszkańców, włącznie z Betlejem;

$\square$ plan pokojowy saudyjskiego księcia Fahda z 3 sierpnia 1982 roku: 1) Izrael wycofa się z palestyńskich obszarów okupowanych i ze wschodniej Jerozolimy, która zostanie stolicą arabskiego państwa palestyńskiego; 2) ONZ odpowiedzialny za jerozolimskie miejsca kultu;

wspólny plan z 1991 roku dr Nusseiby (Palestyna) i dr Heller (Izrael): 1) podział Jerozolimy na wschodnią (arabską) i zachodnią (izraelską) z otwartymi przejazdami; 2) wspólna stolica; 3) miejsca święte pod władzą każdej z religii.

\section{Starzy Mesjasze w nowych szatach rozgrywają Górę Świątynną}

Sądzę, że trudno wątpić w piorunującą siłę Wojny Sześciodniowej (1967 r.), rozgorączkowanie terroryzmu islamskiego i nowego chrześcijańskiego gracza na arenie polityki światowej. Te nowe (lub odnowione) siły są bezsprzecznie wspólczesnym fenomenem. Raymond Aron, wielki politolog francuski, głosił stanowczo, że upadek totalitarnych: czerwonych, brązowych i czarnych reżimów otwiera świat na erę humanizmu i liberalizmu.

Dziennikarz Akiva Eldar i historyk Idith Zeldar wydali w roku 2005, w języku hebrajskim, książkę pod tytułem Władcy tego kraju i potraktowali ją jako ostrze skierowane przeciw mesjanistycznej kolonizacji żydowskiej, uzurpującej sobie prawa do połaci Palestyny zamieszkałej przez Arabów ${ }^{7}$. Motto tej książki jest cytatem syna byłego głównego rabina Tzvi Yehudy Kooka. W wolnym tłumaczeniu brzmi ono: „Pan Bóg ma swoistą politykę na naszym padole (...) część początków powrotu Mesjasza wypowiada się ponownym odbiciem tego kraju i żadna świecka polityka (temu dziełu) nie sprosta". Jeden z rozdziałów tego opracowania autorzy opatrzyli znamiennym tytułem Odgłosy apokalipsy, podając statystyczne dane ofiar (w tysiącach) po obu stronach "barykady".

Zrodzony żydowski mesjanizm i antyliberalny, zachowawczy neomesjanizm ewangelicki nie były przewidziane przez Raymonda Arona.

Już w roku 1979 pisałem w swojej książce: „The Nationalistic camp, strongly influenced by messianic-fundamentalistic religious-Orthodoxy, pays lip service to Jabotinsky, using him as a leading common denominator of the Israeli Right. It

7 A. Eldar, I. Zeldar, Lords of the Land: The War for Israel's Settlements in the Occupied Territories, 1967-2007, Dvir publishing house, Izrael, 2005. 
is only natural that the Right should express emotional and political understanding toward Orthodox religious demands while having no moral nor political obligations toward the non-orthodox, mainly liberal, and even anticlerical Jews in America, who are so sensitive to universal issues of freedom and equality and who are frequently critical of Israeli domestic and international affairs. The newly born Israeli right-wing establishment is developing good relations with the American Orthodox minority. This American orthodoxy is expressing its growing appreciation to the American right wins as well"8.

Publikacje, włącznie z moimi spostrzeżeniami, były jedynie skromnym pokłosiem autentycznych wypadków, które tragicznie wiły się wokół Jerozolimy.

W sierpniu 1969 roku australijski chrześcijanin Denis Michael Rohan został zatrzymany przez policję izraelską w trakcie próby podpalenia meczetu Al Aqsa $\mathrm{w}$ Jerozolimie. $W$ wyroku sprawca został uznany za niepoczytalnego i poddany ekstradycji do Australii.

W tym roku izraelskie Ministerstwo ds. Religii, pod egidą narodowo-religijnego ministra dr. Yosefa Burga, dokonało podkopu pod Górę Świątynną, wbrew dyrektywom rządu.

Przejdźmy jednak do roku 1973. Nathan Lerner - Żyd, członek „Ligi” rabina Kahany, emigrant ze Stanów Zjednoczonych, wychowanek prestiżowego MIT - rozpoczął akcję agitacyjną za pomocą ulotek: „Kultura Izraela nie jest w stanie współżyć z cywilizacją Zachodu (...) ludzkie działania są bez sensu, chyba że spełniają wolę Boga (...)".

Lerner prowadził ze mną dialog i przekonywał, że ustawodawstwo parlamentarne jest niegodne, ponieważ należy działać jedynie pod rygorem wyższej, boskiej rangi.

\section{Judasz Eskariota}

Dziś koniunktura polityczna tak w Izraelu w przeddzień wyborów parlamentarnych, jak w Stanach Zjednoczonych, oparte są na republikańskim senacie Donalda Trumpa, a przede wszystkim - na wzrastającym poparciu ruchu ewangelickiego.

Ruch tradycyjnych luteranów i całej plejady nie-katolickich chrześcijan, włącznie z baptystami i zielonoświątkowcami, miał od lat stosunek ambiwalentny do historycznej roli Judasza Eskarioty, a szczególnie do przypisywanej Judaszowi winy zdrady Chrystusa. Fundamentaliści ewangeliccy wersję zdrady odrzucili, co

8 U. Huppert, Back to the ghetto, Prometheus Books, 1979. 
ułatwiło im polityczną współpracę z izraelskimi Żydami, a szczególnie z prawicą izraelską i anty-świeckim mesjanizmem.

Dramatyczne odkrycie archeologiczne w Egipcie, rozpowszechnione przez prestiżowy miesięcznik „National Geographic” (kwiecień 2006 r.) nadało współpracy z izraelskimi, narodowo-religijnymi i prawicowymi politykami, dodatkowy impet. Archeolodzy odkryli chrześcijański tekst w języku koptyjskim, uważany za niewłączoną do Nowego Testamentu ewangelię Judasza.

Ewangelia ta przedstawia wersję, podług której Judasz dokonał aktu wskazania Chrystusa na prośbę samego Chrystusa, by spełnić jego wolę ukrzyżowania. Ten dokument utwierdził sojusz ewangelików mesjanistycznych z prawicą izraelską, której celem jest inkorporowanie arabskiej (okupowanej) Palestyny i bezwarunkowe utwierdzenie Jerozolimy jako suwerennej i niepodzielnej stolicy Izraela. Wszystko to wbrew dziesiątkom akademickich oraz politycznych propozycji i usankcjonowanych decyzją ONZ.

\section{Nowa krucjata ewangelików}

Cel teologów ewangelicznych jest naturalnie diametralnie różny od świeckiego interesu Państwa Izrael. Jest on również sprzeczny z teologią mesjanistów żydowskich. O tym się nie mówi, jednak warto wspomnieć, jak ważne są współczesne akty polityczne.

Decyzja Stanów Zjednoczonych o uznaniu Jerozolimy za stolicę Izraela odbiła się negatywnym echem tak wśród Palestyńczyków, jak w świecie katolickim oraz Moskwie i kościołach wschodnich. Obiektywni obserwatorzy obawiają się, że nie jest to droga do rozwiązania konfliktu religijnego i politycznego.

David Smith, waszyngtoński komentator brytyjskiego liberalnego dziennika “The Guardian”, w relacji z wtorku 15 maja 2018 r. pisze: „It was a historic and bloody day for Israel (...)The selections of pastors Robert Jeffress and John Hagee was a sign of how for some Christians the recognition of Jerusalem as Israel's capital in consistent with the biblical prophesy of the second coming of Jesus Christ (...)" i dalej: "(...) it was also illustrative of how central the evangelical constituency has become to Donald Trump's suport”, a odnosząc się do sceny izraelskiej: „it was an important show of solidarity with hardline Israeli prime minister Beniamin Netaniahu".

Moskwa, walcząca od stuleci o prymat na Bliskim Wschodzie, ma ponownie swoje bazy w Syrii, a Izrael straszy sąsiadów i zagraża muzułmanom swymi zapędami mesjanistycznymi.

Narzuca się dramatyczna analogia historyczna, a raczej sarkastyczny wybryk, jakże niedawno chyba nie do pojęcia. 
Krzyżowcy, wyruszający z Europy chrześcijańskiej na Bliski Wschód, by uwolnić Ziemię Świętą i Jerozolimę od Saracenów („bezbożnych” muzułmanów), ćwiczyli swe rycerskie umiejętności, przeprowadzając masowe mordy i pogromy, których dokonywali na europejskich „potomkach Judasza”. Pogromy te były preludium do hiszpańskiej inkwizycji i niemieckiego Holokaustu.

Dziś, paradoksalnie, prawicowy premier Izraela, wsparty rodzimymi mesjanistami, stoi wraz z pastorami chrześcijańskich ewangelików w wojnie przeciwko muzułmańskim autochtonom.

Ta mesjanistyczna prawica izraelska przeobraziła, jakże zbytecznie, rozwiązywalny konflikt narodowy, w wojnę religijną, w której współczesna ekipa rządząca w Izraelu zbratała się z neo-chrześcijańskimi ewangelikami, tym samym odrzucając świecką koncepcję założycieli Izraela.

Założyciele żydowskiego ruchu narodowego byli świadomi, że jedynie Kneset - świecki parlament - a nie Wzgórze Świątynne, ma być realizacją zapowiedzi powrotu narodu do biblijnej ojczyzny.

Moskwa, sprytnie powiązana tak z Iranem (szyitami), jak z pewnymi państwami arabskimi (sunnickimi) i wsparta przez prawosławie prze kościoły wschodnie staje się czynnikiem, który odbije swój ślad na Bliskim Wschodzie.

Obawiam się, że te konflikty, nolens volens, skoncentrują się w Jerozolimie.

Rzuca się w oczy historyczny paradoks polityki koalicji mesjanistów. Współcześnie nowi ewangeliccy chrześcijanie prowadzą swą krucjatę rękoma izraelskiego przywódcy, pełniącego funkcję „Wielkiego Mistrza Zakonu Ewangelickiego”.

W przeddzień oddania do druku tego artykułu dramatyczne osłabienie pozycji Stanów Zjednoczonych w Syrii wzmacnia Moskwę Putina i zapowiada ingerencję Rosji w konflikt palestynsko-izraelski i w pozycję Jerozolimy z uszczerbkiem dla ewangelików i żydowskich mesjanistów i grozi politycznym upadkiem premiera Benjamina Netanjahu związanego z chrześcijańską prawicą amerykańską.

\section{Bibliografia}

Eldar A., Zeldar I., Lords of the Land: The War for Israel's Settlements in the Occupied Territories, 1967-2007, Dvir publishing house, Izrael, 2005.

Górny M., Kreślarze ojczyzn, PAN, Warszawa 2018.

Huppert U., Back to the ghetto, Prometheus Books, 1979.

Huppert U., Izrael w cieniu fundamentalizmów, Wydawnictwo Adam Marszałek, Torun 2016.

Łach S., Geneza mesjanizmu biblijnego, „Ruch Biblijny i Liturgiczny” 1970, nr 4-5, s. 167. Patek A., Birobidżan. Sowiecka ziemia obiecana, wyd. Historia Iagellonica, Kraków 1997. Shumski D., Beyond the National State, Yale University Press 2019. 